\title{
Dual Relationships Between Transformational Leadership Perceptions and Organizational Commitment: A Preliminary Research
}

\author{
Evren Ayranci (PhD) \\ Istanbul AREL University, Faculty of Economics and Administrative \\ Sciences Istanbul, Turkey
}

Doi: 10.19044/esj.2017.v13n28p18 URL:http://dx.doi.org/10.19044/esj.2017.v13n28p18

\begin{abstract}
Business environment has always been addressed by various scientific studies via many subjects, theories, and paradigms. While some of these have been very popular in the literature, some have not attained much concern. This study emphasizes two of the very prominent subjects, namely transformational leadership and organizational commitment. What are characteristic to this study are that the existence of top managers' leadership feature (if any) are interpreted by the workers; workers express the extent to which they perceive their top managers as transformational leaders; and workers' organizational commitment is investigated to unearth any potential relationships with this transformational leadership perception. These relationships are expected to be reciprocal. In other words, it is expected that workers' organizational commitment affects and is affected by how much they perceive their top managers as transformational leaders. This expectation is tested in İstanbul Tuzla Organized Industrial Zone by a model proposed with the intentions of finding related facts about Turkish businesses, and reaching some implications about connections between transformational leadership's nature and organizational commitment. The main result acknowledges this expectation: there is a positive and moderate reciprocal connection.
\end{abstract}

Keywords: Transformational leadership, organizational commitment, top managers, organized industrial zones

\section{Introduction}

Business environment is an utmost source of research for many reasons. It has many different analysis levels ranging from global to individual, contains very homogeneous and different types of businesses, enables researchers to consider groups of various businesses in terms of 
formations such as alliances and networks, shows great variability according to contextual changes, and contains many formal and informal issues simultaneously. The result is a complexity that is composed of countless theories, paradigms, and approaches.

This current study intends to make a contribution to two very popular subjects. While one is leadership, the other is organizational commitment. Leadership has really been a noteworthy subject since the ancient times and has started to be researched extensively since the dawn of the 20th century (e.g. Terman, 1904). Organizational commitment, on the other hand, is a newer subject and a vast scientific curiosity has turned towards this subject since 1970s (e.g. Buchanan, 1974; Porter, Steers, Mowday, \& Boulian, 1974).

Despite their abundance in terms of research, some gaps are remarkable. There are many leadership paradigms and transformational leadership is usually posited to affect businesses very positively (e.g. DeGroot, Kiker, \& Cross, 2000). On the other hand, leadership is not expected to be given as a formal authority, leadership position has to be earned. This obligation should turn the attention towards followers' perceptions about the so-called leader - if followers do not perceive their expected leaders as leaders, then it can not be scientifically posited that there is a leader. In other words, followers' perceptions can constitute the leader. An investigation of the relevant literature unfortunately points out that there is really a faint emphasis on these perceptions. One of the aims of this study is to contribute to scientific research regarding these mentioned perceptions in the business context. Deficiency of Turkish studies that share this approach renders this study's contribution more valuable. Organizational commitment is similar to leadership in that it contains many different paradigms ranging from side-bet theory (Alutto, Hrebiniak, \& Alonso, 1973) to the tripartite approach (Allen \& Meyer, 1990). Though organizational commitment is extensively scrutinized in national and international literature, results about its possible connections with leadership in business context are far from being conclusive. These connections are checked in this study while keeping in mind that perceptions about transformational leadership should be taken into account. The scarcity of similar studies and theoretical claims about bi-lateral effects direct this current study to consider the possibility of reciprocal connections.

\section{Transformational leadership's significance in business context}

Leadership is indeed a complex matter for two reasons. It is one of the most scientifically handled subject (Kuchler, 2008) and embraces various approaches (Tal \& Gordon, 2016). Despite its roots from the very early times of humanity (Antonakis, 2017), scientific curiosity and therefore research 
towards this subject dates back to onset of the $20^{\text {th }}$ century (e.g. Mumford, 1909; Terman, 1904) albeit some scientific attempts in the previous century (e.g. Galton, 1869). All this interest and the abundance of approaches give rise to the consideration of leadership in a vast variety of fields ranging from religion (Worthington, 2016), politics (Ferreira \& Gyourko, 2014), and military (Masland \& Lyons, 2015) to sports (Mills \& Boardley, 2017) and business (Watson \& Reissner, 2014).

When attention turns to business context specifically, leadership is generally claimed to provide benefits at individual (Liden, Wayne, Liao, \& Meuser, 2014), group (Mohammed \& Alipour, 2014), and organizational levels (Ding, Li, \& George, 2014). These benefits are not limited to be supplied by more conventional leadership approaches such as transactional (Wahyuni, Christiananta, \& Eliyana, 2014) or transformational (Epitropaki \& Martin, 2013), but some few and newer studies also find out that other approaches like innovation (Chassagnon \& Haned, 2015) or spiritual (Afsar, Badir, \& Kiani, 2016) leadership are beneficial as well.

Among all approaches, transformational leadership is generally granted as the one that evolved the entire perception about leadership (Hunt, 1999). This grant emerges from the fact that the leader appeals to feelingness and sensitivity of followers (Herman \& Chiu, 2014) by means of emphasizing the importance and meaning of objectives (Bormann \& Rowold, 2016), and motivating followers with a related long term vision for the sake of all (Bass \& Avolio, 1997). A striking point is that the leader accomplishes all these while denoting an interest towards the needs and desires of followers (Bass, 1985), and therefore followers directly or indirectly play a role in setting up the objectives and the vision (Tafvelin, Hyvönen, \& Westerberg, 2014). In other words, followers unite with the leader and the leadership process. This unity has some very positive outcomes. While a privileged one is followers' commitment towards the objectives and the long term vision (Bass, 1998); other outcomes are followers' inspiration and altruism (Choudhary, Kumar, \& Philip, 2016), high level of effectiveness (Schepers, Wetzels, \& de Ruyter, 2005), creativity (Mumford, Scott, Gaddis, \& Strange, 2002), and innovative problem-solving (Jaskyte, 2004).

These mentioned features have aroused interest of many scholars and the requirement of businesses' transformation in the name of adaptation and survival (Kennerley, Neely, \& Adams, 2003) emphasizes research on transformational leadership in business context. Similar to leadership in general, transformational leadership is found out to be very useful at multiple levels in business context (e.g. Judge \& Piccolo, 2004). A thorough investigation of this usefulness reveals that it pays off by means of many aspects. For instance, this type of leadership is a very powerful source of 
worker motivation (Bono \& Judge, 2003); ends up with a greater task and organizational commitment (DeGroot et al., 2000); leads to effective decision-making of managers and altruism of workers simultaneously, which result in a better organizational performance (Gong, Huang, \& Farh, 2009); positively affects workers' job satisfaction (Ghanbari \& Eskandari, 2014); increases workers' absorption of businesses' psycho-social atmosphere and thus the feeling of synergy (Colbert, Kristof-Brown, Bradley, \& Barrick, 2008); inspires innovative problem-solving (Sarros, Cooper, \& Santora, 2008); and contributes to trust among workers and managers, and therefore collaboration (Barling, Slater, \& Kelloway, 2000).

An in-depth inquisition about these positive outcomes' mechanism points out some noteworthy facts. As explained earlier, a transformational leader empowers followers by actively involving them in goal setting and visioning processes, and simultaneously acts sensitively towards followers. Such actions of transformational leader result in a participative and innovative environment for workers in business context (Zhou \& Shalley, 2008), which in turn ensures workers' altruism (Kvaloy \& Schöttner, 2015), task motivation (Bottomley, Mostafa, Gould-Williams, \& León-Cázares, 2016), identification with the business and the leader (Wang \& Howell, 2012), and trust towards the leader (Breevaart, Bakker, Demerouti, Sleebos, \& Maduro, 2015) and among each other (Bartram \& Casimir, 2007). Leader's promotion of a participative and innovative environment can also result in a better job satisfaction; not only by means of workers' positive feelings due to being actively engaged in goal-setting and visioning process, but also by leader's promotion of freedom towards workers' tasks (Kellett, Humphrey, \& Sleeth, 2002).

Literature also stresses that benefits of this leadership type are tightly connected with workers' perceptions of the leader. As mentioned earlier, followers constitute the leader and this fact is evident in business studies. More precisely, workers' perceptions about how the leader considers their motivation (Shin \& Zhou, 2003), intellectual creative capacity (Dong, Bartol, Zhang, \& Li, 2017), personal needs (Kovner, Brewer, Wu, Cheng, \& Suzuki, 2006), values associated with their tasks (Breevaart et al., 2015) and their freedom regarding these tasks (Kark, Shamir, \& Chen, 2003) are critical factors for effective transformational leadership.

\section{Relationships between transformational leadership and organizational commitment in business context}

Since Becker (1960), organizational commitment has been a popular destination of scientific research and various studies have been made to understand the nature and importance of this subject. A general view is that organizational commitment is a very good indicator of workers' attitude 
towards the business (Morrow, 1993) and is also a good predictor of positive and negative outcomes regarding turnover intentions (Cohen, 1993; DeConinck \& Bachmann, 1994), organizational citizenship behavior (Moorman, Niehoff, \& Organ, 1993; Sinclair, Tucker, Cullen, \& Wright, 2005), job satisfaction (Rusu, 2013; Tett \& Meyer, 1993), organizational trust (Laschinger, Finegan, \& Shamian, 2001), and finally, transformational leadership (Bushra, Ahmad, \& Naveed, 2011; Gillet \& Vandenberghe, 2014).

Though transformational leadership and organizational commitment have some connections, these connections may or may not be accompanied by other factors. A famous accompanier is job satisfaction (e.g. Emery \& Barker, 2007; Mitchell, 2015) and it is mostly asserted that transformational leadership and job satisfaction can simultaneously affect organizational commitment (Tanner, 2007) while there is also some proof that the connections between leadership and job satisfaction are moderated by organizational commitment (Chi, Tsai, \& Chang, 2007). Another prominent component is creativity: the leader provides empowerment with the expectation that this empowerment will result in greater worker creativity (Walumbwa \& Lawler, 2003) and this creativity will act as a catalyst to foster organizational commitment (Jaiswal \& Dhar, 2015).

Omitting any accompanier implies a one-way connection. Transformational leadership is found out to encourage workers' organizational commitment by means of leader's personal sensitivity towards each worker (Bycio, Hackett, \& Allen, 1995), involvement of workers in objective setting and visioning processes (Bass \& Avolio, 1994), expression of workers' importance (Walumbwa, Wang, Lawler, \& Shi, 2004), and personally developing workers through experience and knowledge sharing (Kark \& Shamir, 2002). In addition to these findings, the multi-dimensional nature of organizational commitment (e.g. Allen \& Meyer, 1990), convinces some researchers to scrutinize each dimension distinctively. Besides the fact that transformational leadership has effects on all dimensions through empowerment (Wiley, 1999); outcomes clearly reveal that transformational leader's promotion of empowerment affects affective dimension of organizational commitment to the utmost (Avolio, Zhu, Koh, \& Puja, 2004).

\section{Methodology}

Literature insists that transformational leadership is effective on organizational commitment, though some points still need clarification. One is the need to consider transformational leader's involvement of workers in goal-setting and visioning processes. This involvement suggests an active interaction between the leader and workers. Moreover, leader's customized approach and sensitivity towards each worker implies possible changes in 
leadership behaviors due to how workers act towards the leader and business issues. As mentioned before, organizational commitment is a good indicator of workers' attitudes regarding business environment, thus their behaviors towards business issues. A convenient expectation, in this case, would be to see leadership behavior changes due to workers' organizational commitment changes. This expectation - reciprocity - has not been thoroughly tested in the literature, which should be clarified. The second point has already been discussed before; leadership should be inspected according to the perceptions of workers in a business setting, which has not been done in relation to organizational commitment before. The author forms the model in Figure 1 in order to elucidate these points.

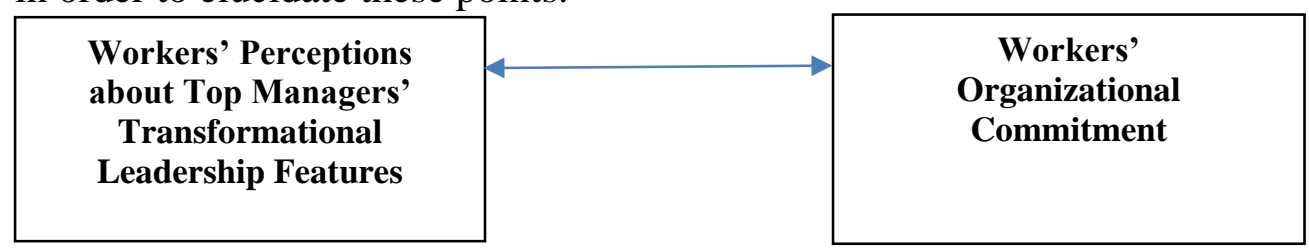

Figure 1. Proposed research model Figure 1:

The hypothesis of the research is based on the research model in

$\mathrm{H}_{\mathrm{A}}$ : There is a reciprocal connection between workers' perceptions about top managers' transformational leadership features and their organizational commitment.

All businesses in İstanbul Tuzla Organized Industrial Zone (OIZ) are considered and currently this OIZ hosts 96 businesses officially (İstanbul Tuzla OSB, 2017). The author considers equivalent presentation of each business but a problem persists - business sizes in terms of the number of business members vary profoundly. A quick telephone check with the businesses reveals that the smallest business contains four business members while the biggest involves 39 members. Although the use of quota sampling, depending on the number of business members, seems to be the most convenient approach; this can not be exerted as some businesses are not willing to share their number of members. This compels the author to stick to the incomplete data about number of business members. As the data point out the smallest business to be composed of four business members and at least one member is expected to be the manager, it is proper to get data from three workers from each business. Thus, data from a total of 288 workers are collected.

Data are collected via questionnaires and a professional consulting firm is used to collect data. The names of participants and their contact information are gathered by this firm in the form of a list, and this list is 
given to the author. The author checks with the participants to confirm that the questionnaires are correctly applied.

Questionnaires are composed of two parts. While the first part deals with transformational leadership perceptions of the workers towards their top managers, the second part pays regard to workers' organizational commitment. The consideration of Turkish context necessitates customized instruments. Therefore, organizational commitment is analyzed via Porter et al.'s (1974) instrument that has also been used in the Turkish context (e.g. Erdem, 2007). Perceptions about transformational leadership, on the other hand, are evaluated by means of combining two instruments used in Turkish context (Baloglu, Karadag, \& Gavuz, 2009; Korkmaz, 2005), which depend on studies of Bass and Avolio (1990), and Bass and Avolio (1995).

\section{Statistical structures}

Statistical structures and reliabilities of the data are scrutinized and these structures are taken into consideration in order to test the model in Figure 1. When explanatory factor analyses, using principal components analysis, varimax rotation and suppression of factor loadings less than $|0,5|$, are run for both transformational leadership perceptions and organizational commitment items, structures in Tables 1 and 2 are formed. These tables also contain reliability analyses' results.

Table 1. Statistical structure and reliability results of transformational leadership perceptions

\begin{tabular}{|c|c|c|}
\hline KMO Value & $\begin{array}{c}\text { Inspirational } \\
\text { Visioning } \\
\text { (IV) }\end{array}$ & $\begin{array}{c}\text { Personal Sensitivity } \\
\text { (PS) }\end{array}$ \\
\hline Variance Explained (\%) & $\begin{array}{c}\text { (Bartlett's test value is statistically } \\
\text { significant at 5\%) }\end{array}$ \\
\hline Reliability Value (Cronbach's Alpha) & 31,363 & 26,956 \\
\hline My top manager has a clear vision. (IV1) & 0,871 & 0,818 \\
\hline My top manager acts purposefully for the sake of us all. \\
(IV3) & 0,901 & 0,874 \\
\hline $\begin{array}{c}\text { My top manager emphasizes collaboration towards } \\
\text { business mission. (IV4) }\end{array}$ & 0,866 & \\
\hline My top manager acts optimistically. (IV2) & 0,862 & 0,825 \\
\hline My top manager talks enthusiastically. (IV5) & 0,813 & 0,819 \\
\hline My top manager expresses confidence to each of us. \\
(PS1)
\end{tabular}


My top manager helps each of us to develop our task skills. (PS4)

0,702

Extraction Method: Principal Component Analysis.

Rotation Method: Varimax with Kaiser Normalization.

Rotation converged in 4 iterations.

Table 1 presents the very nature of transformational leadership inspirational visioning and personal sensitivity. While inspirational visioning involves setting up the vision, considering the collective good, fostering collaboration, and promoting inspiration through optimistic and enthusiastic approaches; personal sensitivity covers a constructive personal interest of the leader towards each worker in terms of confidence, attention, care, and development.

Though organizational commitment is popular with its threedimensional structure (Allen \& Meyer, 1990), Table 2 reveals that only two dimensions are active regarding the data at hand.

Table 2. Statistical structure and reliability results of organizational commitment

\begin{tabular}{|c|c|c|}
\hline KMO Value & $\begin{array}{c}\text { Affective } \\
\text { Commitment } \\
\text { (AC) }\end{array}$ & $\begin{array}{c}\text { Continuance } \\
\text { Commitment } \\
\text { (CC) }\end{array}$ \\
\hline Variance Explained (\%) & \multicolumn{2}{|c|}{$\begin{array}{c}0,801 \\
\text { (Bartlett's test value is statistically } \\
\text { significant at 5\%) }\end{array}$} \\
\hline Reliability Value (Cronbach's Alpha) & 38,955 & 21,547 \\
\hline I am very happy to work in this business. (AC3) & 0,862 & 0,729 \\
\hline I am proud to be a member of this business. (AC2) & 0,922 & 0,914 \\
\hline $\begin{array}{c}\text { I am ready to exert extra performance to keep this business } \\
\text { successful. (AC1) }\end{array}$ & 0,868 & \\
\hline I can accept any position in this business to keep being a \\
member. (AC4)
\end{tabular}


Table 2 emphasizes affective and continuance components of organizational commitment. Affective component is about positive feelings of workers towards their businesses such as happiness and proud, and implies possible altruism of workers in terms of providing extra performance and position swaps in their businesses. Continuance component, beside, remarks the extent to which workers are willing to stick to their businesses when they consider personal development, ease of finding alternative jobs, and changes in their current situation.

\section{Relationship testing:}

The next step is to test the model in Figure 1. As statistical structures are revealed, these structures may now be shown integrally in this model. This necessitates the model to be expressed in details, as shown in Figure 2.

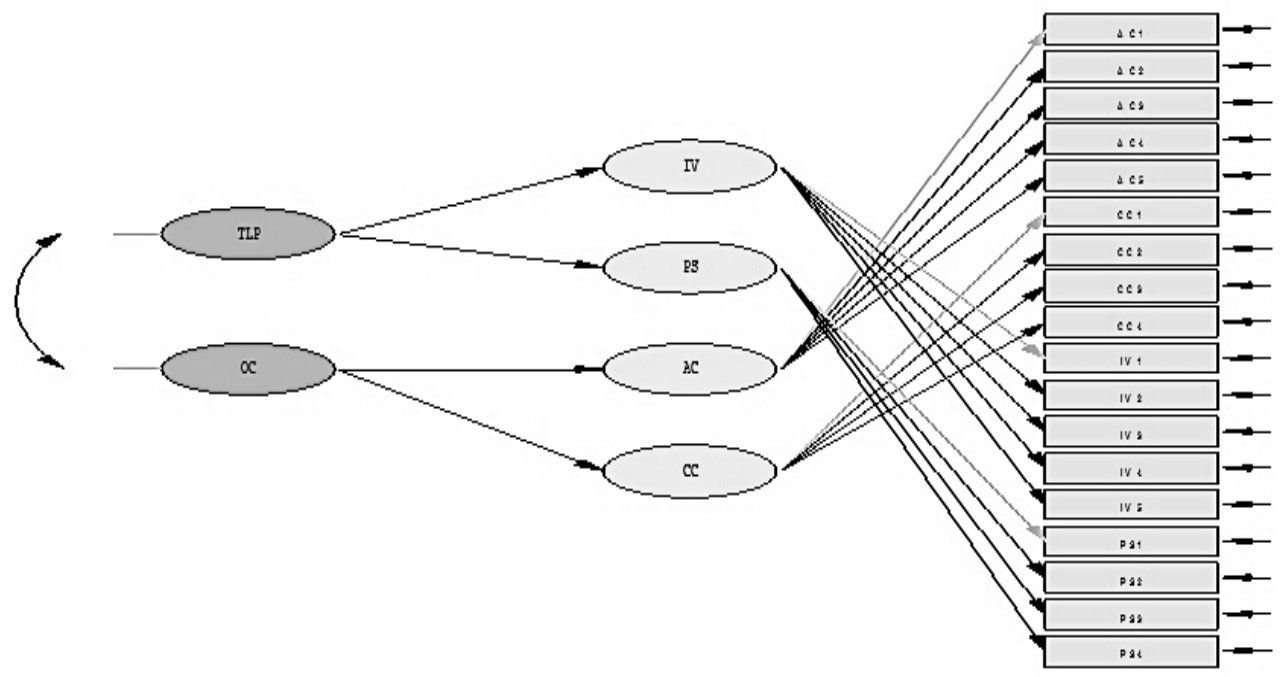

Figure 2. Research model in details

(TLP: Transformational Leadership Perceptions, OC: Organizational Commitment, Other abbreviations can be found in Tables 1 and 2).

Table 3 presents the fit indices of the detailed model in Figure 2 and it confirms that the model is realistic aggregately.

Table 3. Fit indices of the research model

\begin{tabular}{|c|c|c|c|}
\hline Goodness of Fit Index (GFI) & 0,95 & Relative Fit Index (RFI) & 0,97 \\
\hline $\begin{array}{c}\text { Adjusted Goodness of Fit Index } \\
\text { (AGFI) }\end{array}$ & 0,93 & $\begin{array}{c}\text { Root Mean Square Error of } \\
\text { Approximation (RMSEA) }\end{array}$ & 0,11 \\
\hline $\begin{array}{c}\text { Parsimony Goodness of Fit Index } \\
\text { (PGFI) }\end{array}$ & 0,84 & $\begin{array}{c}\text { Root Mean Square Residual } \\
\text { (RMR) }\end{array}$ & 0,059 \\
\hline Comparative Fit Index (CFI) & 0,96 & Standardized RMR & 0,094 \\
\hline Incremental Fit Index (IFI) & 0,95 & & \\
\hline
\end{tabular}


This situation is also acknowledged once the model's standardized errors are checked to comply with normal distribution (Figure 3).
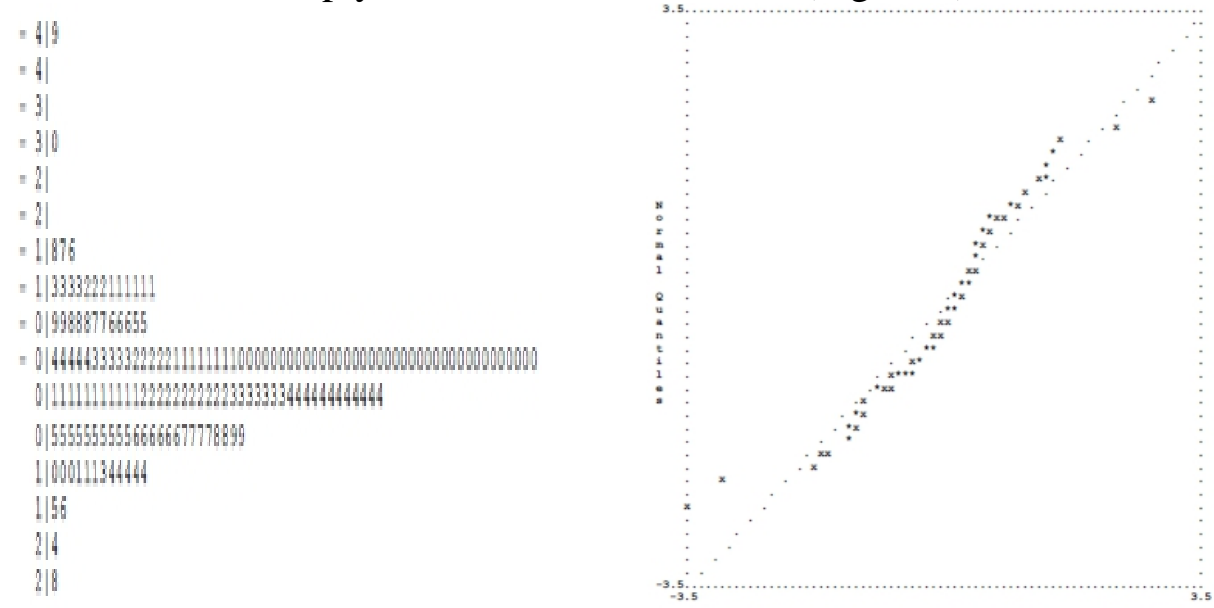

Figure 3. Stemleaf and Q - plots of the model's standardized errors

When relationships within this model are investigated, three more tables emerge. The first one, Table 4, signifies that all relationships regarding transformational leadership perceptions are statistically significant.

Table 4. Relationships regarding transformational leadership perceptions

\begin{tabular}{|c|c|c|c|}
\hline & Coefficient & t-value & $\mathrm{R}^{2}$ \\
\hline $\begin{array}{c}\text { Relationships at latent variable level } \\
\text { Transformational Leadership Perceptions - Inspirational } \\
\text { Visioning (IV) }\end{array}$ & 0,28 & 4,84 & 0,39 \\
\hline $\begin{array}{c}\text { Transformational Leadership Perceptions - Personal } \\
\text { Sensitivity (PS) }\end{array}$ & 0,21 & 3,50 & 0,44 \\
\hline $\begin{array}{c}\text { Relationships at variable level } \\
\text { Inspirational Visioning (IV) - My top manager has a clear } \\
\text { vision. (IV1) }\end{array}$ & 0,76 & - & 0,98 \\
\hline $\begin{array}{c}\text { Inspirational Visioning (IV) - My top manager acts } \\
\text { optimistically. (IV2) }\end{array}$ & 0,46 & 5,08 & 0,68 \\
\hline $\begin{array}{c}\text { Inspirational Visioning (IV) - My top manager acts } \\
\text { purposefully for the sake of us all. (IV3) }\end{array}$ & 0,82 & 4,92 & 0,70 \\
\hline $\begin{array}{c}\text { Inspirational Visioning (IV) - My top manager } \\
\text { emphasizes collaboration towards business mission. } \\
\text { (IV4) }\end{array}$ & 0,44 & 5,00 & 0,77 \\
\hline $\begin{array}{c}\text { Inspirational Visioning (IV) - My top manager talks } \\
\text { enthusiastically. (IV5) }\end{array}$ & 0,20 & 3,11 & 0,34 \\
\hline $\begin{array}{c}\text { Personal Sensitivity (PS) - My top manager expresses } \\
\text { confidence to each of us. (PS1) }\end{array}$ & 1,17 & - & 0,98 \\
\hline $\begin{array}{c}\text { Personal Sensitivity (PS) - My top manager gives special } \\
\text { attention to each of us. (PS2) }\end{array}$ & 1,24 & 27,03 & 0,96 \\
\hline $\begin{array}{c}\text { Personal Sensitivity (PS) - My top manager } \\
\text { individualizes care. (PS3) }\end{array}$ & 1,41 & 25,99 & 0,93 \\
\hline $\begin{array}{c}\text { Personal Sensitivity (PS) - My top manager helps each of } \\
\text { us to develop our task skills. (PS4) }\end{array}$ & 0,74 & 24,08 & 0,79 \\
\hline \begin{tabular}{c} 
(II) \\
\hline
\end{tabular}
\end{tabular}


Table 4 also expresses that both inspirational visioning and personal sensitivity components are positively and moderately contributing to workers' transformational leadership perceptions of their top managers. An interesting outcome is that all items have positive relationships with their respective components and aside from some (e.g. IV5), these relationships are powerful. The findings from Table 4 again abridge the already mentioned nature of transformational leadership.

The next table, Table 5, emphasizes a similar result for organizational commitment - all relationships about this commitment are also statistically significant.

Table 5. Relationships regarding organizational commitment

\begin{tabular}{|c|c|c|c|}
\hline & Coefficient & t-value & $\mathrm{R}^{2}$ \\
\hline \multicolumn{4}{|l|}{ Relationships at latent variable level } \\
\hline $\begin{array}{c}\text { Organizational Commitment - Affective } \\
\text { Commitment }(A C)\end{array}$ & 0,63 & 3,68 & 0,34 \\
\hline $\begin{array}{c}\text { Organizational Commitment - Continuance } \\
\text { Commitment }(C C)\end{array}$ & 0,11 & 3,18 & 0,23 \\
\hline \multicolumn{4}{|l|}{ Relationships at variable level } \\
\hline $\begin{array}{l}\text { Affective Commitment (AC) - I am ready to exert } \\
\text { extra performance to keep this business successful. } \\
\text { (AC1) }\end{array}$ & 0,97 & - & 0,91 \\
\hline $\begin{array}{l}\text { Affective Commitment (AC) - I am proud to be a } \\
\text { member of this business. (AC2) }\end{array}$ & 1,12 & 19,23 & 0,92 \\
\hline $\begin{array}{l}\text { Affective Commitment (AC) - I am very happy to } \\
\text { work in this business. (AC3) }\end{array}$ & 1,21 & 19,07 & 0,94 \\
\hline $\begin{array}{c}\text { Affective Commitment (AC) - I can accept any } \\
\text { position in this business to keep being a member. } \\
\text { (AC4) }\end{array}$ & 0,65 & 16,72 & 0,82 \\
\hline $\begin{array}{l}\text { Affective Commitment (AC) - I think this is one of } \\
\text { the best businesses that I can be employed. (AC5) }\end{array}$ & 0,75 & 17,67 & 0,86 \\
\hline $\begin{array}{c}\text { Continuance Commitment }(C C) \text { - If I leave this } \\
\text { business, my current situation will not get much } \\
\text { worse. }{ }^{*}(\mathrm{CC} 1)\end{array}$ & 0,57 & - & 0,64 \\
\hline $\begin{array}{c}\text { Continuance Commitment }(C C) \text { - If tasks are } \\
\text { similar, I could easily work in a different business. } \\
\text { (CC2) }\end{array}$ & 0,75 & 3,99 & 0,79 \\
\hline $\begin{array}{c}\text { Continuance Commitment }(C C) \text { - I do not think that } \\
\text { I can develop myself if I work in this business for a } \\
\text { long time. }{ }^{*}(\mathrm{CC} 3)\end{array}$ & 0,55 & 4,05 & 0,43 \\
\hline $\begin{array}{c}\text { Continuance Commitment }(C C) \text { - Working in this } \\
\text { business is a mistake. }(\mathrm{CC} 4)\end{array}$ & 0,71 & 3,96 & 0,39 \\
\hline${ }^{*}$ Inversely keyed. & & & \\
\hline
\end{tabular}

Findings about organizational commitment (Table 5) resembles those of transformational leadership perceptions - while affective and continuance commitment components contribute to organizational commitment 
positively, albeit less moderately; each item also has a positive and generally, strong connection with its own component.

The ultimate result is given by the final table - Table 6. It directly shows how workers' perceptions about their top managers' transformational leadership feature and their organizational commitment are inter-related.

Table 6. Correlation between transformational leadership perceptions and organizational commitment

\begin{tabular}{|c|c|c|}
\hline & $\begin{array}{c}\text { Transformational Leadership } \\
\text { Perceptions }\end{array}$ & $\begin{array}{c}\text { Organizational } \\
\text { Commitment }\end{array}$ \\
\hline Transformational Leadership & & 0,67 \\
Perceptions & 1,00 & $(0,03)$ \\
& & 3,19 \\
\hline Organizational Commitment & 0,67 & 1,00 \\
& $(0,03)$ & \\
\hline
\end{tabular}

Table 6 depictures a moderate and positive relationship between the perceptions and organizational commitment. The literature outlines that transformational leadership practices enforces organizational commitment as already explained. When transformational leadership perceptions are construed instead of practices, a dual relationship between these perceptions and organizational commitment appears. In this case, the hypothesis of the research is accepted.

\section{Conclusion and suggestions}

The literature submits evidence that transformational leadership provides positive outcomes for businesses by means of its effects on various issues. One such issue is organizational commitment and results obtained epitomize this leadership style's positive effects on workers' organizational commitment. Related studies, however, sometimes overlook the complexity of human relationships. In other words, humans interact and thus leadership issues can not be taken into consideration unilaterally. This aspect enacts the author to consider transformational leadership from followers' point of view and for that matter, followers (workers) are asked to express their perceptions about their business top managers' transformational leadership potentiality. The mentioned complexity and human interaction issues, moreover, canalize the author to assume dual relationships between workers' perceptions and their organizational commitment. Put another way, it is assumed that how workers perceive their top managers as transformational leaders should be able to affect their organizational commitment and vice versa. 
The main result achieved exactly demonstrates this dual relationship and the positive connection implies a congruence with the literature. When workers assign greater levels of transformational leadership feature to their top managers, they also tend to show greater levels of organizational commitment. On the contrary, when they are more committed to their businesses, they agree that their top managers exert more transformational leadership features.

Sub-results screen two main facts. First, the very nature of transformational leadership features is extracted - workers speculate that their top managers have inspiration, vision, and personalized approach. Second, workers' organizational commitment has affective and continuance components.

These results could propound some implications. As told earlier, organizational commitment is workers' general attitude towards their businesses by and large, and workers are the key to organizational success. Under these circumstances, top managers could assume transformational leadership role. This role, nevertheless, should be internalized by workers in order to foster their commitment. Internalization could be possible if there is an effective communication between the leader and workers; and effectiveness is linked with a personalized approach towards each worker and a participative environment for goal-setting and visioning, which are exactly the already established features of transformational leaders.

Many suggestions may flourish to overarch the limitations of this study. This study only addresses transformational leadership but future studies could check other leadership styles' effects on organizational commitment. Instead of solely considering workers' perceptions of their top managers' leadership features, prospective studies could add these managers' perceptions about their own leadership features besides workers' perceptions. Future studies could also check for leadership perceptions about managers at multiple levels simultaneously. Future models may also be enhanced by some additions such as personality features, or perceptional differences. Different types of businesses or businesses from different cultures may also be noted for model testing. It is also evident that managers should take leadership courses and actively engage in exerting leadership behaviors towards workers.

\section{References:}

1. Afsar, B., Badir, Y., \& Kiani, U. S. (2016). Linking spiritual leadership and employee pro-environmental behavior: The influence of workplace spirituality, intrinsic motivation, and environmental passion. Journal of Environmental Psychology, 45, 79-88. 
2. Allen, N. J., \& Meyer, J. P. (1990). The measurement and antecedents of affective, continuance and normative commitment to the organization. Journal of Occupational Psychology, 63(1), 1-18.

3. Alutto, J. A., Hrebiniak, L. G., \& Alonso, R. C. (1973). On operationalizing the concept of commitment. Social Forces, 51, 448454.

4. Antonakis, J. (2017). The nature of leadership. Thousand Oaks, California: Sage Publications.

5. Avolio, B. J., Zhu, W., Koh, W., \& Puja, B. (2004). Transformational leadership and organizational commitment: Mediating role of psychological empowerment and moderating role of structural distance. Journal of Organizational Behavior, 25, 951-968.

6. Baloglu, N., Karadag, E., \& Gavuz, S. (2009). Effect of school principles' multi-factor leadership styles on authority turnover: A structural equation modeling study (in Turkish). Journal of Uludag University Education Faculty, 22, 457-479.

7. Barling, J., Slater, F., \& Kelloway, E. K. (2000). Transformational leadership and emotional intelligence: An exploratory study. Leadership \& Organization Development Journal, 21(3), 157-161.

8. Bartram, T., \& Casimir, G. (2007). The relationship between leadership and follower in-role performance and satisfaction with the leader: The mediating effects of empowerment and trust in the leader. Leadership \& Organization Development Journal, 28(1), 4-19.

9. Bass, B. M. (1985). Leadership and performance beyond expectations. New York: Free Press.

10. Bass, B. M. (1998). Transformational leadership: Industrial, military, and educational impact. Mahwah, NJ: Lawrence Erlbaum Associates, Incorporated.

11. Bass, B. M., \& Avolio, B. J. (1990). Transformational leadership development: Manual for the multifactor leadership questionnaire. Palo Alto, CA: Consulting Psychologists Press.

12. Bass, B. M., \& Avolio, B. J. (1994). Improving organizational effectiveness through transformational leadership. Thousand Oaks, CA: Sage Publications.

13. Bass, B. M., \& Avolio, B. J. (1995). MLQ, multifactor leadership questionnaire sampler set: Technical report, leader form, rater form, and scoring key for MLQ form. New York: Center for Leadership Studies, Binghamton University.

14. Bass, B. M., \& Avolio, B. J. (1997). Full range leadership development: Manual for the multifactor leadership questionnaire. Palo Alto, CA: Mind Garden. 
15. Becker, H. S. (1960). Notes on the concept of commitment. American Journal of Sociology, 66(1), 32-40.

16. Bono, J. E., \& Judge, T. A. (2003). Self-concordance at work: Toward understanding the motivational effects of transformational leaders. Academy of Management Journal, 46, 554-571.

17. Bormann, K. C., \& Rowold, J. (2016). Transformational leadership and followers' objective performance over time: Insights from German basketball. Journal of Applied Sport Psychology, 28, 367373.

18. Bottomley, P., Mostafa, A. M. S., Gould-Williams, J. S., \& LeónCázares, F. (2016). The impact of transformational leadership on organizational citizenship behaviours: The contingent role of public service motivation. British Journal of Management, 27, 390-405.

19. Breevaart, K., Bakker, A. B., Demerouti, E., Sleebos, D. M., \& Maduro, V. (2015). Uncovering the underlying relationship between transformational leaders and followers' task performance. Journal of Personnel Psychology, 13(4), 194-203.

20. Buchanan, B. (1974). Building organizational commitment: The socialization of managers in work organizations. Administrative Science Quarterly, 19, 533-546.

21. Bushra, F., Ahmad, U., \& Naveed, A. (2011). Effect of transformational leadership on employees' job satisfaction and organizational commitment in banking sector of Lahore (Pakistan). International Journal of Business and Social Science, 2(18), 261-267.

22. Bycio, P., Hackett, R. D., \& Allen, J. S. (1995). Further assessments of Bass's (1985) conceptualization of transactional and transformational leadership. Journal of Applied Psychology, 80, 468478.

23. Cohen, A. (1993). Organizational commitment and turnover: A met a-analysis. Academy of Management Journal, 36, 1140-1157.

24. Colbert, A. E., Kristof-Brown, A. L., Bradley, B. H., \& Barrick, M. R. (2008). CEO transformational leadership: The role of goal importance congruence in top management teams. Academy of Management Journal, 51(1), 81-96.

25. DeConinck, J. B., \& Bachmann, D. P. (1994). Organizational commitment and turnover intentions of marketing managers. Journal of Applied Business Research, 10(3), 87-95.

26. DeGroot, T., Kiker, D. S., \& Cross, T. C. (2000). A meta-analysis to review organizational outcomes related to charismatic leadership. Canadian Journal of Administrative Sciences, 17, 356-372. 
27. Ding, F., Li, D., \& George, J. F. (2014). Investigating the effects of IS strategic leadership on organizational benefits from the perspective of CIO strategic roles. Information \& Management, 51, 865-879.

28. Dong, Y., Bartol, K. M., Zhang, Z. X., \& Li, C. (2017). Enhancing employee creativity via individual skill development and team knowledge sharing: Influences of dual-focused transformational leadership. Journal of Organizational Behavior, 38, 439-458.

29. Emery, C. R., \& Barker, K. J. (2007). The effect of transactional and transformational leadership styles on the organizational commitment and job satisfaction of customer contact personnel. Journal of Organizational Culture, Communication and Conflict, 11(1), 77-90.

30. Epitropaki, O., \& Martin, R. (2013). Transformational-transactional leadership and upward influence: The role of relative leader-member exchanges (RLMX) and perceived organizational support (POS). Leadership Quarterly, 24, 299-315.

31. Erdem, R. (2007). The relationship between organizational culture types and organizational commitment: A study on hospitals in Elazı̆ city center. (in Turkish). Journal of Eskisehir Osmangazi University, 2(2), 63-79.

32. Ferreira, F. V., \& Gyourko, J. (2014). Does gender matter for political leadership? The case of US mayors. Journal of Public Economics, 112, 24-39.

33. Galton, F. (1869). Hereditary genius. London: Macmillan.

34. Ghanbari, S., \& Eskandari, A. (2014). Transformational leadership, job satisfaction, and organizational innovation. International Journal of Management Perspective, 1(4), 81-94.

35. Gillet, N., \& Vandenberghe, C. (2014). Transformational leadership and organizational commitment: The mediating role of job characteristics. Human Resource Development Quarterly, 25, 321347.

36. Gong, Y., Huang, J. C., \& Farh, J. L. (2009). Employee learning orientation, transformational leadership, and employee creativity: The mediating role of employee creative self-efficacy. Academy of Management Journal, 52, 765-778.

37. Herman, H. M., \& Chiu, W. C. K. (2014). Transformational leadership and job performance: A social identity perspective. Journal of Business Research, 67, 2827-2835.

38. Hunt, J. G. (1999). Transformational/charismatic leadership's tranformation of the field: An historical essay. Leadership Quarterly, 10(2), 129-144.

39. Chassagnon, V., \& Haned, N. (2015). The relevance of innovation leadership for environmental benefits: A firm-level empirical analysis 
on French firms. Technological Forecasting and Social Change, 91, 194-207.

40. Chi, H., Tsai, H., \& Chang, P. (2007). Investigating the relationship among leadership styles, emotional intelligence and organization commitment on job performance: A study of salespeople in Thailand. Journal of Human Resource and Adult Learning, 3(2), 199-212.

41. Choudhary, N., Kumar, R., \& Philip, P. J. (2016). Effects of transformational leadership on follower's organizational citizenship behavior: The moderating role of culture. Prabandhan: Indian Journal of Management, 9(7), 23-35.

42. İstanbul Tuzla OSB (2017). Operating firms (in Turkish). Retrieved from http://www.itosb.org.tr/_firmalar/itosb_firma_listesi.pdf (Accessed 3 September 2017).

43. Jaiswal, N. K., \& Dhar, R. L. (2015). Transformational leadership, innovation climate, creative self-efficacy and employee creativity: A multilevel study. International Journal of Hospitality Management, 51, 30-41.

44. Jaskyte, K. (2004). Transformational leadership, organizational culture, and innovativeness in nonprofit organizations. Nonprofit Management and Leadership, 15(2), 153-168.

45. Judge, T. A., \& Piccolo, R. F. (2004). Transformational and transactional leadership: A meta-analytic test of their relative validity. Journal of Applied Psychology, 89, 755-768.

46. Kark, R., \& Shamir, B. (2002). The dual effect of transformational leadership: Priming relational and collective selves and further effects on followers. In J. Avolio \& F. J. Yammarino (Eds.), Transformational and charismatic leadership: The road ahead (pp. 67-91). St. Louis, MO: Elsevier.

47. Kark, R., Shamir, B., \& Chen, G. (2003). The two faces of transformational leadership: Empowerment and dependency. Journal of Applied Psychology, 88, 246-255.

48. Kellett, J. B., Humphrey, R. H., \& Sleeth, R. G. (2002). Empathy and complex task performance: Two routes to leadership. Leadership Quarterly, 13, 523-544.

49. Kennerley, M., Neely, A., \& Adams, C. (2003). Survival of the fittest: Measuring performance in a changing business environment. Measuring Business Excellence, 7(4), 37-43.

50. Korkmaz, M. (2005). Effect of emotions and leadership styles on teachers' performance (in Turkish). Educational Administration: Theory and Practice, 11, 401-422. 
51. Kovner, C., Brewer, C., Wu, Y. W., Cheng, Y., \& Suzuki, M. (2006). Factors associated with work satisfaction of registered nurses. Journal of Nursing Scholarship, 38(1), 71-79.

52. Kuchler, W. J. (2008). Perceived leadership behavior and subordinates' job satisfaction in midwestern NCAA division III athletic departments. Sport Journal, 11(2), 23-35.

53. Kvaloy, O., \& Schöttner, A. (2015). Incentives to motivate. Journal of Economic Behavior \& Organization, 116, 26-42.

54. Laschinger, H. K. S., Finegan, J., \& Shamian, J. (2001). The impact of workplace empowerment, organizational trust on staff nurses' work satisfaction and organizational commitment. Healthcare Management Review, 26(3), 7-23.

55. Liden, R. C., Wayne, S. J., Liao, C., \& Meuser, J. D. (2014). Servant leadership and serving culture: Influence on individual and unit performance. Academy of Management Journal, 57, 1434-1452.

56. Masland, J. W., \& Lyons, G. M. (2015). Education and military leadership. A study of the ROTC. New Jersey: Princeton University Press.

57. Mills, J. P., \& Boardley, I. D. (2017). Advancing leadership in sport: Time to 'actually' take the blinkers off? Sports Medicine, 47, 565570.

58. Mitchell, D. E. (2015). The relationship of transformational leadership behaviors with organizational commitment, job satisfaction, and productivity at one investment services company in the Mid-Atlantic region (Doctoral dissertation). Wilmington University Delaware, USA.

59. Mohammed, S., \& Alipour, K. K. (2014). It's time for temporal leadership: Individual, dyadic, team, and organizational effects. Industrial and Organizational Psychology, 7(2), 178-182.

60. Moorman, R. H., Niehoff, B. P., \& Organ, D. W. (1993). Treating employees fairly and organizational citizenship behavior: Sorting the effects of job satisfaction, organizational commitment, and procedural justice. Employee Responsibilities and Rights Journal, 6, 209-225.

61. Morrow, P. C. (1993). The theory and measurement of work commitment. Greenwich, CT: JAI Press.

62. Mumford, E. (1909). The origins of leadership. CA: University of Chicago Press.

63. Mumford, M. D., Scott, G. M., Gaddis, B., \& Strange, J. M. (2002). Leading creative people: Orchestrating expertise and relationships. Leadership Quarterly, 13, 705-750. 
64. Porter, L. W., Steers, R. M., Mowday, R. T., \& Boulian, P. V. (1974). Organizational commitment, job satisfaction, and turnover among psychiatric technicians. Journal of Applied Psychology, 59, 603-609.

65. Rusu, R. (2013). Organizational commitment and job satisfaction. Scientific Bulletin-Nicolae Balcescu Land Forces Academy, 18(1), 52-55.

66. Sarros, J. C., Cooper, B. K., \& Santora, J. C. (2008). Building a climate for innovation through transformational leadership and organizational culture. Journal of Leadership \& Organizational Studies, 15(2), 145-158.

67. Shin, S. J., \& Zhou, J. (2003). Transformational leadership, conservation, and creativity: Evidence from Korea. Academy of Management Journal, 46, 703-714.

68. Schepers, J., Wetzels, M., \& de Ruyter, K. (2005). Leadership styles in technology acceptance: Do followers practice what leaders preach? Managing Service Quality, 15, 496-508.

69. Sinclair, R. R., Tucker, J. S., Cullen, J. C., \& Wright, C. (2005). Performance differences among four organizational commitment profiles. Journal of Applied Psychology, 90, 1280-1287.

70. Tafvelin, S., Hyvönen, U., \& Westerberg, K. (2014). Transformational leadership in the social work context: The importance of leader continuity and co-worker support. British Journal of Social Work, 44, 886-904.

71. Tal, D., \& Gordon, A. (2016). Leadership of the present, current theories of multiple involvements: A bibliometric analysis. Scientometrics, 107(1), 259-269.

72. Tanner, B. M. (2007). Analysis of the relationships among job satisfaction, organizational trust, and organizational commitment in an acute care hospital (Doctoral dissertation). Saybrook Graduate School and Research Center, San Francisco, CA.

73. Terman, L. M. (1904). A preliminary study in the psychology and pedagogy of leadership. Pedagogical Seminary, 11, 413-483.

74. Tett, R. P., \& Meyer, J. P. (1993). Job satisfaction, organizational commitment, turnover intention, and turnover: Path analyses based on meta-analytic findings. Personnel Psychology, 46, 259-293.

75. Wahyuni, D. U., Christiananta, B., \& Eliyana, A. (2014). Influence of organizational commitment, transactional leadership, and servant leadership to the work motivation, work satisfaction and work performance of teachers at private senior high schools in Surabaya. Educational Research International, 3(2), 82-96.

76. Walumbwa, F. O., \& Lawler, J. J. (2003). Building effective organizations: Transformational leadership, collectivist orientation, 
work-related attitudes and withdrawal behaviours in three emerging economies. International Journal of Human Resource Management, 14, 1083-1101.

77. Walumbwa, F. O., Wang, P., Lawler, J. J., \& Shi, K. (2004). The role of collective efficacy in the relations between transformational leadership and work outcomes. Journal of Occupational and Organizational Psychology, 77, 515-530.

78. Wang, X. H., \& Howell, J. M. (2012). A multilevel study of transformational leadership, identification, and follower outcomes. Leadership Quarterly, 23, 775-790.

79. Watson, G., \& Reissner, S. (2014). Developing skills for business leadership. London: Kogan Page Publishers.

80. Wiley, D. M. (1999). Impact of locus of control and empowerment on organizational commitment (Doctoral dissertation). United States International University, Kenya.

81. Worthington, L. (2016). Progressive islam and women's religious leadership: Analysing the emergence of new models of shared authority. Journal for the Academic Study of Religion, 29(2), 167181.

82. Zhou, J., \& Shalley, C. E. (2008). Handbook of organizational creativity. New York, NY: Lawrence Erlbaum Associates. 